\title{
DOLLARIZATION AND ECONOMIC INTERDEPENDENCE: THE CASE OF ECUADOR
}

\author{
DOLARIZACION E INTERDEPENDENCIA ECONOMICA: \\ EL CASO DE ECUADOR
}

\author{
RAMON A. CASTILLO-PONCE* \\ California State University, Los Angeles and Universidad Autónoma de Baja California
}

\author{
BRIAN TRUONG** \\ California State University, Los Angeles
}

\section{MARIA DE LOURDES RODRIGUEZ-ESPINOSA***}

Universidad Tecnológica de la Mixteca

\begin{abstract}
Economic theory suggests that dollarization increases the degree of interdependence between the dollarized economy and the anchor country. We test this theory for the case of the U.S. and Ecuador. We perform cointegration and common cycles tests for data at the aggregate and industry levels. The results show that the economies of the U.S. and Ecuador were interrelated prior to dollarization. The interrelation increased after Ecuador adopted the U.S. dollar. This finding holds true for various Ecuadorian industries. Synchronization for the case of the financial industry is particularly revealing, as it shows how dollarization leads to the integration of financial markets.
\end{abstract}

Keywords: Dollarization, Business Cycles Synchronization, Economic Integration, Financial Integration.

JEL Classification: E42, F44, F33.

\footnotetext{
* California State University, Los Angeles and Universidad Autónoma de Baja California. 5151 State University Drive, Los Angeles, CA 90032. E-mail: rcastil@calstatela.edu

** California State University, Los Angeles. 5151 State University Drive, Los Angeles, CA 90032. E-mail: btruon18@calstatela.edu

*** Universidad Tecnológica de la Mixteca. Carretera a Acatlima Km. 2.5, Huajuapan de León, Oaxaca, Mexico. E-mail: mdlrodrig@mixteco.utm.mx
} 


\section{Resumen}

La teoría económica sugiere que la dolarización incrementa el grado de interdependencia entre la nación que se dolariza y la nación madre. Probamos esta teoría para el caso de Estados Unidos y Ecuador. Llevamos a cabo pruebas de cointegración y ciclos comunes considerando datos agregados y desagregados por industria. Los resultados muestran interrelación entre las economías antes de la dolarización. La misma aumentó después de que Ecuador adoptara el dólar. Este resultado es cierto para algunas industrias ecuatorianas. La sincronización en el caso de la industria financiera es particularmente reveladora, mostrando cómo la dolarización conlleva a la integración de mercados financieros.

Palabras clave: Dolarización, Sincronización de Ciclos Económicos, Integración Económica, Integración Financiera.

Clasificación JEL: E42, F44, F33.

\section{INTRODUCTION}

Since the implementation of dollarization in the late 1990s, policy makers and academicians have debated its benefits and costs without having reached a consensus on the net effect of this policy. What is the overall effect of dollarization at the aggregate level? There is no definite answer for this question. While it is accepted that adopting a strong currency leads to the reduction of inflation, interest rates, and the stabilization of the economy, it is also known that dollarization may negatively affect the competitiveness of exports and ultimately economic growth. Also, the adopting country loses the ability to implement monetary policy and exercise seigniorage. Thus, it is not surprising to find that existing literature on dollarization reports mixed results of its overall effect. For example, Gonzalez et al. (2015) show that dollarization reduces transaction costs and facilitates financial integration. Similarly, Lakic et al. (2016) find that Montenegro's euroization "unequivocally" led to a decrease in inflation and allowed assets in the banking system to grow nine times since the introduction of the euro. On the other hand, Rodriguez and Dombrow (2015) argue that dollarization slowed economic growth in El Salvador, noticeably in the real estate market. Moreover, Sandoval et al. (2015) suggest that adopting the U.S. dollar in El Salvador had no positive and significant impact on its imports and exports. More recently, Yepes (2016) shows that growth in Ecuador and El Salvador post dollarization most probably comes from changes in productivity and commodity prices, not from adopting the U.S. dollar. ${ }^{1}$

1 Other venues analyzing dollarization include the effect of this policy with respect to fiscal sustainability. See Marí del Cristo and Gómez-Puig (2016) for instance. 
In this document, we depart from traditional approaches to analyzing the effects of dollarization and focus on one that has received relatively little attention in the literature: economic synchronization. While the effects of dollarization on various economic indicators have been amply studied, the effect of the policy on the dynamic of the business cycles of the anchor and adopting countries has not. This is particularly interesting, since economic theory suggests that one of the "benefits" of dollarization is that economic activity across countries will become more interrelated. Specifically, dollarization reduces transaction costs and allows for a more stable economic environment. According to Musa (1986), a floating exchange rate between two countries leads to higher variance in the real exchange rate. Thus, the adoption of a common currency would eliminate the volatility; allowing less risk associated with the relative prices and resulting in more trade between countries. Furthermore, Berg and Borensztein (2000) notice that integration goes beyond the goods market; financial markets may also become more integrated. They point to the reduction in currency risk and the associated decrease in financial vulnerability, which may produce a more robust banking system in the adopting country. The authors discuss the case of Panama, whose financial market has become more integrated with financial markets in the U.S. ${ }^{2}$

For our exercise, we consider production data for Ecuador, which is available at the aggregate and industry levels. What do we expect to find? At the aggregate level, if economic theory holds true, we should find that after Ecuador dollarized, its economy became more synchronized with the U.S. economy. At the industry level, however, the expected results are not as predictable. Synchronization would likely happen if an industry is highly associated with economic activity in the U.S., otherwise there should be no reason for synchronization. That is, if an industry depends significantly on the economic performance of the U.S., perhaps because it is an export-oriented industry, then it is reasonable to assume that production cycles will be synchronized. If an industry's output does not depend on demand from the U.S., then synchronization is less likely to take place. We test the degree of interdependence for long horizons and for transitory periods. To that end, we conduct cointegration tests to identify the existence of common trends amongst the variables, and common cycle tests to determine if the series exhibit common features in the short-run. The existence of a common trend would suggest that economic activity in Ecuador responds significantly to permanent changes in the performance of the U.S. economy; sharing common cycles would mean that the variables behave in a similar manner in response to transitory shocks.

While finding evidence of cointegration or the existence of common cycles amongst Ecuador and U.S. variables after the adoption of the U.S. dollar will suggest that dollarization led to the synchronization of their economies, we should note that the analysis we conduct faces a notable challenge. Specifically, it is well known that

2 Lindenberg and Westermann (2012) estimate the degree of codependence between the economies of the U.S. and various Latin American economies, including El Salvador, for the sample period 1997 2008. The authors find that there is no codependence amongst these two countries. 
in the past the world economy has experienced the surge of super cycles, particularly in commodity prices. The result of these super cycles is that economic variables across countries may have become more synchronized. As such, it is possible that synchronization of Ecuador and U.S. variables may not necessarily be the result of dollarization, but a consequence of these super cycles. Ideally, one would conduct an exercise to disentangle the source of synchronization when common cycles are identified. However, data availability makes such exercise extremely challenging. Nonetheless, we present an exercise that points to dollarization as the source of common movements across economic variables. The same considers financial variables, whose dynamics are not likely to be associated with super cycles. We believe that the analysis presented below convincingly shows how dollarization produced a closer relationship between Ecuadorian and U.S. economic variables.

The rest of the document is organized as follows: in Section I we summarize Ecuador's dollarization experience and examine the performance of some economic indicators before and after dollarization. If economic theory holds true, it must be the case that economic variables in Ecuador after dollarization have become more aligned with their U.S. counterparts. Section II presents the data and describes the methodological approach. Section III conducts the econometric exercise, which consists of determining the stochastic nature of the variables and conducting the cointegration and common cycle tests. Section IV concludes.

\section{SECTION I. DOLLARIZATION IN ECUADOR}

For small open economies suffering from chronic crises and instability, dollarizing seems an appropriate policy, after all, economic theory suggests significant benefits from this strategy, including low inflation, low interest rates, economic stability, and reduced currency risk. If an economy desires to cast aside economic misfortune, robust macroeconomic conditions are essential. In the early 2000s, El Salvador and Ecuador decided to adopt the U.S. dollar as their currency. El Salvador abandoned the Colon following years of economic stagnation, erratic output volatility, high inflation, and high interest rates (consequence of the decade-long civil war.) In the case of Ecuador, although the country performed relatively well in the two decades preceding dollarization, the 1999 economic crisis proved significant enough to abandon the Sucre. Specifically, with the exception of the early 1980s when economic performance was weak due to the Latin American debt crisis, the country reported robust growth for most of the 1980s and 1990s. Following a year of hyperinflation in 1989, average inflation from 1990 to 1998 leveled off at $37.55 \%$, well below average inflation of $60 \%$ experienced in emerging and developing economies. In 1999, however, the economy collapsed. Gross Domestic Product (GDP) dropped almost 5\%, inflation climbed to $52.2 \%$-reaching $96.1 \%$ in 2000 - the Sucre depreciated $70 \%$, interest rates soared, and external debt reached $118 \%$ of GDP. Under these circumstances Ecuador dollarized its economy in 2000 . 
Did dollarization deliver? To some extent it did. El Salvador experienced a significant drop in interest rates and inflation after the adoption of the U.S. dollar, the spread between lending and borrowing rates narrowed; signaling an improvement in the credit market. Output volatility decreased and the overall economic environment stabilized. ${ }^{3}$ For Ecuador, several authors have highlighted the benefits produced by dollarization. Lange and Sauer (2005), for instance, identify lower nominal interest rates, lower inflation, and economic and currency stability after 2000. It is worth mentioning, however, that economic challenges persist, including chronic unemployment and high reserve to deposit ratio, as discussed in Soto (2009). Below we present graphical evidence of the behavior of various economic indicators before and after dollarization. Graph 1 illustrates the lending and borrowing interest rates since 1990. Notice a significant decline in both following dollarization. The average borrowing rate from 1995 to the end of 2000 was $15.09 \%$, while the average from 2001 to the second quarter of 2019 was $8.18 \%$. Graph 2 reports the interest rate spread. A downward trend is evident after 2000. For the past five years the average has been 2.93\%, down from a high of more than $8 \%$ during the 1999 crisis. Graph 3 pairs Ecuador's spread with the spread between the 10-year and 2-year U.S. Treasury Constant Maturity rates. Prior to 2000 the dynamics of these series were clearly distinct; while the spread in Ecuador experienced significant ups and downs from 1995 to 1998, the U.S. spread remained relatively constant. From 2000 onwards the two variables follow very similar behaviors, both increased around the time of the 2008-2009 financial crisis, and then slowly declined until 2015. Their ups and downs over the past three years have been almost identical.

Graph 4 presents inflation rates for Ecuador and the U.S. The drop in inflation in Ecuador and its synchronization with U.S. inflation is striking, especially in the early years after dollarization. It should be noted that not only did the behavior of inflation in Ecuador become more aligned with inflationary dynamics in the U.S., but the levels of inflation also converged. Since 2015 average inflation has been 3.35\% in Ecuador and 2.4\% in the U.S.

3 See Castillo-Ponce and Rodriguez-Espinosa (2009). 


\section{GRAPH 1}

LENDING (ACTIVA) AND BORROWING (PASIVA) INTEREST RATES

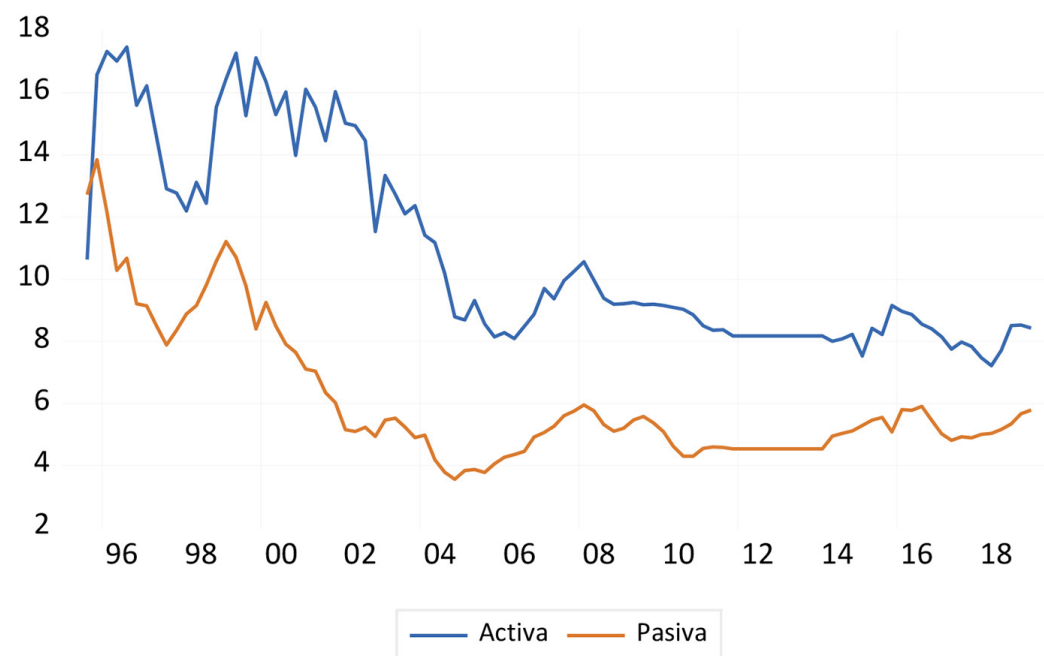

Source: Central Bank of Ecuador.

GRAPH 2

SPREAD BETWEEN BORROWING AND LENDING INTEREST RATES

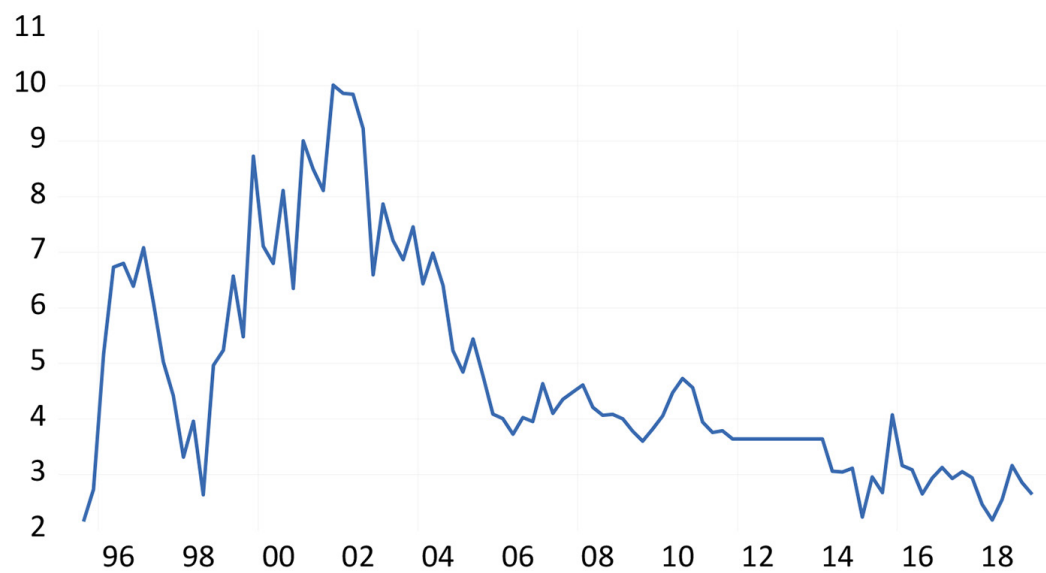

Source: Central Bank of Ecuador. 


\section{GRAPH 3}

INTEREST RATES SPREAD IN ECUADOR AND THE U.S.

12

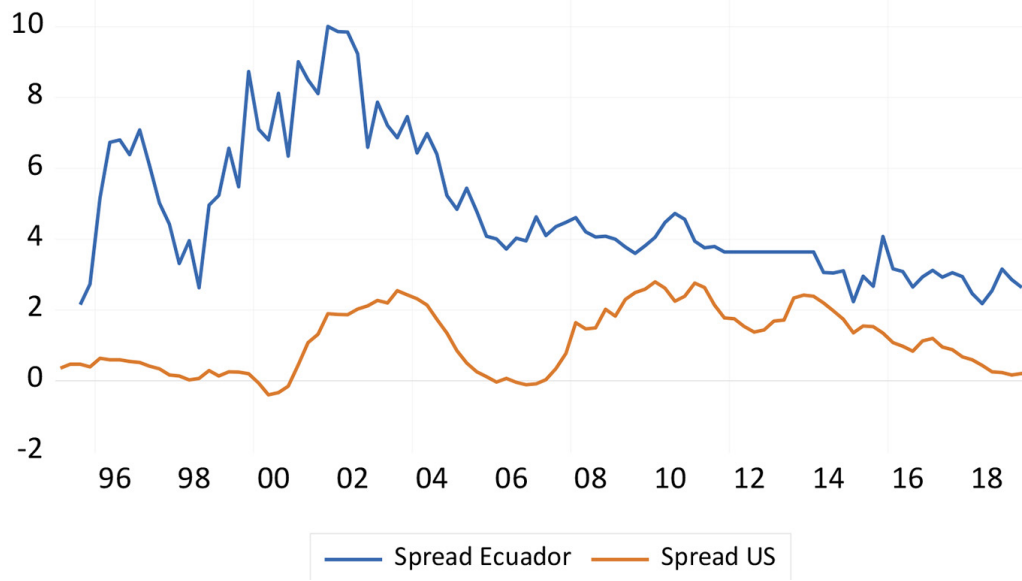

Source: Central Bank of Ecuador.

\section{GRAPH 4}

INFLATION RATES IN ECUADOR AND THE U.S.

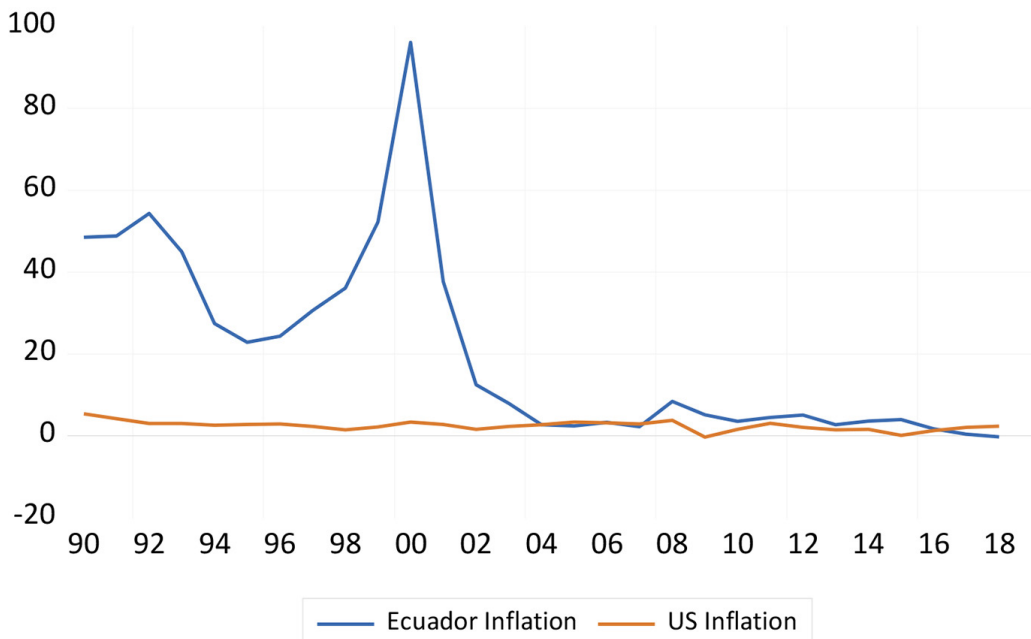

Source: Central Bank of Ecuador and Bureau of Labor Statistics. 
So far, the evidence suggests that interest rates and inflation responded positively to dollarization. What about economic performance? Graph 5 presents the growth rate for Ecuador's real GDP. In principle, dollarization should deliver a more stable and robust economy, which appears to be true from the graphical evidence. In fact, from 1983 to 2000 standard deviation was 2.40 and the mean growth 2.25. Since dollarization, and up to 2018, standard deviation and growth have been 2.55 and 3.68 respectively. Not an impressive improvement for volatility, but a significant rise in growth.

\section{GRAPH 5}

\section{GDP GROWTH ECUADOR}

10

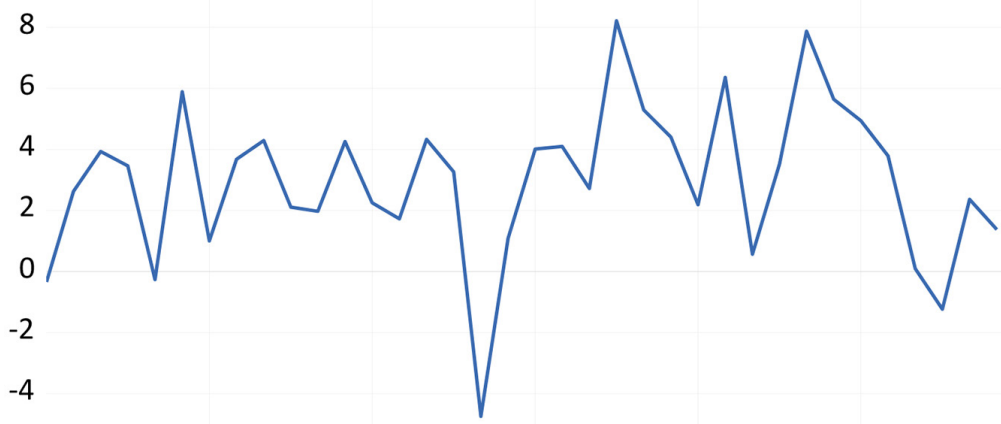

$-6$

$\begin{array}{lllllllllllll}83 & 86 & 89 & 92 & 95 & 98 & 01 & 04 & 07 & 10 & 13 & 16 & 19\end{array}$

Source: Central Bank of Ecuador

While it is clear that dollarization has produced some of the benefits economic theory suggests, including more stable inflation, improvements in financial variables, and economic performance, we would like to evaluate one that, as we indicated in the introduction, has received little attention in the literature: economic synchronization. This is the task we set out to perform in the following sections. 


\section{SECTION II. DATA AND METHODOLOGY}

\section{Section II.I Data}

We consider constant GDP for the U.S. and Ecuador, as well as GDP for various industries in Ecuador. Data for the U.S. comes from the Bureau of Economic Analysis and for Ecuador from the Central Bank of Ecuador. The sample period is from the first quarter of 1990 to the fourth quarter of 2018. Ecuador's industries for which GDP information was available are shown in Table 1.

\section{TABLE 1}

INDUSTRIES INCLUDED IN THE ANALYSIS

\begin{tabular}{|l|l|}
\hline Pre-Dollarization & Post-Dollarization \\
\hline Agriculture & Agriculture \\
Commerce & Agriculture and Fishing (shrimp) \\
Construction & Fishing (No shrimp) \\
Domestic Service & Lodging \\
Utilities & Commerce \\
Financial Services & Construction \\
Manufacturing & Communications \\
Oil & Domestic Service \\
Transport Services & Utilities \\
Other Services & Education and Health \\
& Financial \\
& Manufacturing \\
& Oil and Mining \\
& Professional Services \\
& Public Administration \\
& Oil (refining) \\
& Transport Services \\
& Other Services \\
\hline
\end{tabular}

Notice that the industry classification is not constant prior and post dollarization, and hence, when implementing the econometric exercise direct comparison across the two periods for specific industries will be limited, nonetheless we will formulate an argument describing how the interrelation between industries in Ecuador and economic activity in the U.S. has evolved. As to why the classification is not homogenous, we do not have a definite answer, since an explanation is not readily available at the source of the data; but we can offer an explanation. Consider the case of shrimp and oil, which are two of the largest Ecuadorian exports to the U.S. Prior to dollarization, these industries were bundled with agriculture and oil respectively. After dollarization, 
they were included in more disaggregated categories. This is reasonable, a more precise accounting of the goods representing a large portion of the country's exports might be preferred.

We begin the analysis with a graphic illustration of the joint behavior of the U.S. and Ecuador growth rates. Graph 6 shows GDP growth for both economies prior to dollarization. In some periods, Ecuador's business cycle follows the expansions and recessions in the U.S. For example, in 1993 and 1995 both economies show a slowdown; they both grew from 1996 to 1998 . However, there were episodes when the economies moved in opposite directions. This is the case for the periods 1990-1992 and 1998-2000. In the latter episode, the economy of the U.S. performed robustly, but Ecuador experienced one of the most significant recessions in recent history with GDP dropping more than $8 \%$.

The behavior of the business cycles appears to become more synchronized after dollarization is implemented in 2000. As it is evident in Graph 7, expansions and recessions in the U.S. and Ecuador seem to coincide. Both economies slowed down in 2008 and maintained steady growth from 2010 to 2016. Notice, however, that the turning points in the U.S. cycle appear to precede those in Ecuador. This is clearly the case for 2007. The U.S. economy entered a recession in that year while Ecuador continued to grow, but in 2008, Ecuador's GDP dropped significantly. This leaderfollower dynamic is not evident in the pre-dollarization period. Visual evidence in Graph 6 does not show that fluctuations in Ecuador's GDP follow changes in the U.S. business cycle. This fact is particularly interesting, suggesting that after dollarization Ecuador's economy has been following economic performance in the U.S.; an interdependence similar to what other highly integrated economies with the U.S. exhibit. Take the case of Mexico, for example, as it is well known, the Mexican and U.S. business cycles are synchronized, with fluctuations in Mexico following changes in U.S. cycles. ${ }^{4}$

Overall, the graphical evidence suggests that dollarization led to a closer economic relationship between Ecuador and the U.S.; the econometric exercise we conduct in the next section will provide more grounds for drawing a convincing conclusion.

4 See for example Herrera (2004). 


\section{GRAPH 6}

GDP GROWTH RATES FOR ECUADOR AND THE U.S. PRIOR TO DOLLARIZATION

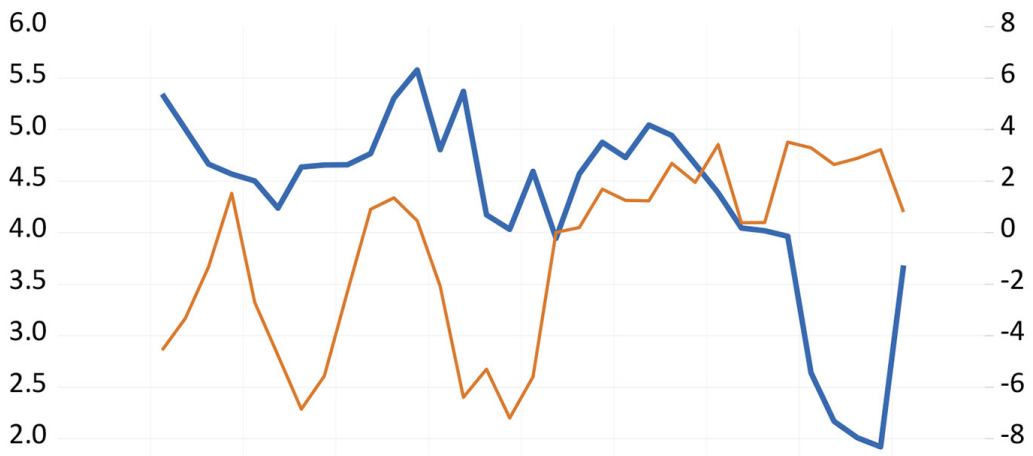

1.5

$\begin{array}{lllllllllll}91 & 92 & 93 & 94 & 95 & 96 & 97 & 98 & 99 & 00^{-10}\end{array}$

- Year \% Change ECUADOR

Year \% Change US

Source: Central Bank of Ecuador and Bureau of Labor Statistics.

\section{GRAPH 7}

GDP GROWTH RATES FOR ECUADOR AND THE U.S. POST DOLLARIZATION

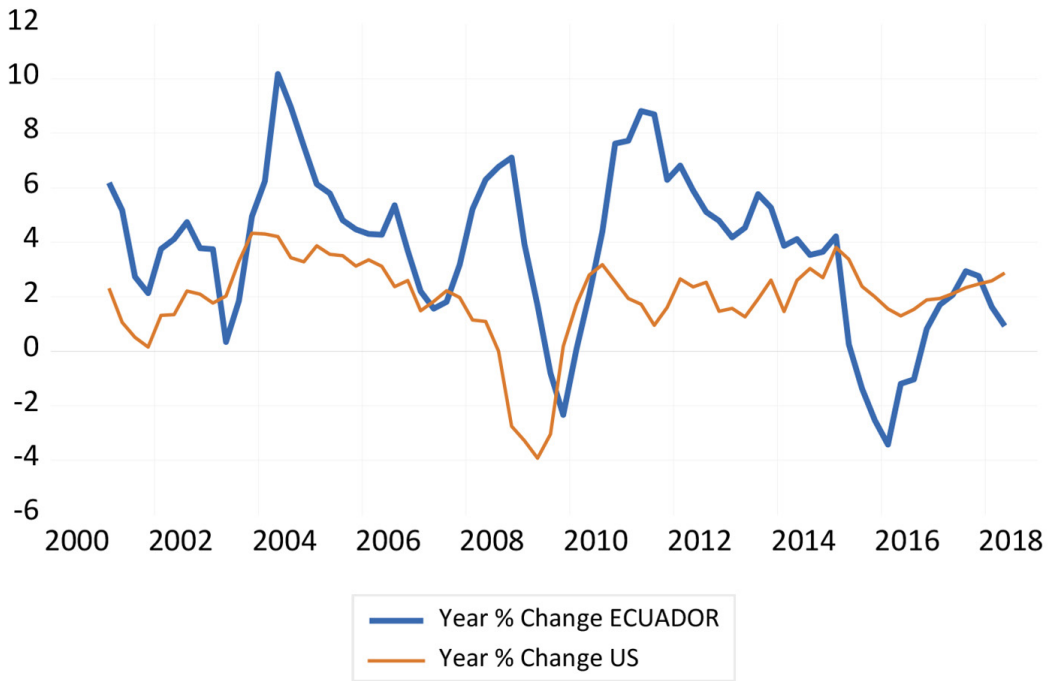

Source: Central Bank of Ecuador and Bureau of Labor Statistics. 


\section{Section II.II Methodology}

The methodology we employ is based on Vahid and Engle (1993). The analysis considers the decomposition of a time series into its trend and cyclical components a lá Beveridge and Nelson (1981):

$$
y_{t}=C(1) \sum_{s=0}^{\infty} u_{t-s}+C^{*}(L) u_{t}
$$

Where the first term on the right hand side of the equation is the trend component and the second the cyclical component. The test for cointegration examines the trend component and the test for common cycles the transitory component. We perform the Johansen (1991) cointegration test and the Vahid and Engle (1993) common cycle test. The Johansen methodology aims at testing whether the trends of the series follow a common trend. It is a widely used methodology for conducting cointegration tests; and hence, we spare the reader of the technical details. The Vahid and Engle methodology, on the other hand, is not as well-known so we provide a brief description of it.

This methodology computes the number of common cycles in the system, $s$. The first step consists of computing the squared canonical correlations, $\lambda^{2}$, and then testing the hypothesis $\lambda_{i}^{2}=0 \quad \forall i=1 \ldots s$. The test statistic is $C(p, s)=-(T-p-1) \sum_{i=1}^{s} \log \left(1-\lambda_{i}^{2}\right)$ and has $\chi^{2}$ distribution with $s^{2}+s n p+s r-s n$ degrees of freedom; where $n$ represents the number of variables in the system, $p$ the optimal lag structure determined in the cointegration test, and $r$ the number of cointegration relations. A probability higher than 0.05 would suggest the existence of a common cycle at conventional critical levels. It is worth noting that finding a common cycle amongst a set of variables, does not imply that there is a significant statistical association between them. It simply means that the cyclical components of the series share common characteristics. For example, they have similar turning points. Thus, in addition to estimating whether the series share a common cycle, we also test for the existence of a statistical significant association following Vahid and Engle (1993). ${ }^{5}$

5 We thank Professor Joao Issler for providing the GAUSS code to implement the test. 


\section{SECTION III. EMPIRICAL EXERCISE}

\section{Section III.I Aggregate Level}

The empirical procedure follows Vahid and Engle (1993). First, cointegration tests are performed, then, conditional on these results, the common cycle tests are conducted. We begin with the analysis of the GDPs. Since the stochastic nature of this variable for Ecuador and the U.S. is widely accepted, they are series integrated of order 1, we do not perform unit root tests and proceed with estimating the cointegration tests. ${ }^{6}$ The results for the prior and post dollarization periods are reported in Table 2. For both periods, there is evidence of the existence of a common trend. Since the cointegrating vector is normalized with respect to Ecuador's GDP, the results suggest that a $1 \%$ variation in the GDP of the U.S. leads to a $1.221 \%$ change in Ecuador's GDP in the pre dollarization period and a $1.891 \%$ adjustment after the year 2000. With respect to the magnitude, these coefficients are larger than coefficients identified for other countries, for example Mexico. Typically, the long-run elasticities of the Mexican economy with respect to the U.S. economy are less than 1 . One explanation for the large elasticities in our exercise, is that Ecuador is a smaller economy than Mexico, and its performance depends significantly on exports to the U.S. We note that this is just an educated guess, clearly, the reason for the large elasticities is a topic that calls for further analysis. For now, we can conclude that the economy of Ecuador has become more responsive to variations in the U.S. economy in the long-run.

\section{TABLE 2}

\section{COINTEGRATION RESULTS FOR GDPS}

\begin{tabular}{|l|c|c|c|}
\hline Ecuador GDP, U.S. GDP & Probability & Normalized Cointegrating Vector & \\
\hline Before Dollarization & 0.001 & 1 & -1.221 \\
After Dollarization & 0.001 & 1 & -1.891 \\
\hline
\end{tabular}

The null hypothesis is No-Cointegrating vector. The cointegration vector is normalized with respect to Ecuador's GDP.

The results for the common cycle tests are reported in Table 3. In this case the outcome is somewhat unexpected but quite interesting. There is evidence that the economies of the U.S. and Ecuador shared a common cycle prior to dollarization, though

6 For the case of the U.S. there is a plethora of documents analyzing the stochastic nature of the series, see for example Perron and Wada (2009). Christopoulos and Tsionas (2004) provide evidence for Ecuador. 
the responsiveness of Ecuador's economy to a transitory shock in the U.S. economy is insignificant; the t-statistic for the coefficient is close to 0 . This is consistent with the graphical evidence we discussed earlier. It appears that the breaking points are somewhat similar, but no clear relationship is apparent between the two economies. For the post dollarization period, the results indicate that the business cycles do not share a common cycle contemporaneously, however, the economy of Ecuador responds significantly to a transitory shock in the U.S. economy; with a coefficient of 0.292 and t-statistic of 2.117. Based on the leader-follower evidence we identified in the graphical analysis, we decided to lag the U.S. business cycle. When we lag the cycle one period, there is evidence of codependence at the 0.043 significance level, and this dependence becomes stronger when the business cycle is lagged two periods; the probability is 0.081 . As for the coefficients, their magnitudes increase as more lags are added, and in all cases they are significant. What these facts suggest, is that the economy of Ecuador responds to transitory shocks in the U.S. with lags. That is, it takes at least one quarter for a slowdown in the U.S., for example, to be reflected in the performance of Ecuador's GDP. This is consistent with the graphical evidence we previously provided and it is intuitive. Consider the case of a decline in aggregate demand in the U.S., producers in Ecuador are unlikely to decrease their production instantaneously; adjustments to a change in the economic environment will reasonably take some time. In this case, it appears that production in Ecuador takes at least one quarter to respond. Overall, the results identify an increase in the correlation between the business cycles in the U.S. and Ecuador, one that increases as more lags are added to economic activity in the U.S.

TABLE 3

COMMON CYCLE RESULTS FOR GDPS

\begin{tabular}{|l|c|c|c|}
\hline Ecuador GDP, U.S. GDP & Probability & $\begin{array}{c}\text { Two Stage Least } \\
\text { Square Estimate }\end{array}$ & t-statistic \\
\hline Before Dollarization & 0.132 & -0.102 & -0.871 \\
After Dollarization U.S. GDP Lagged 0 Quarter & 0.022 & 0.292 & 2.117 \\
After Dollarization U.S. GDP Lagged 1 Quarter & 0.043 & 0.347 & 2.182 \\
After Dollarization U.S. GDP Lagged 2 Quarters & 0.081 & 0.357 & 2.010 \\
\hline
\end{tabular}

The null hypothesis refers to the existence of a common cycle.

As mentioned earlier, this behavior is similar to what has been identified for the case of Mexico and its interrelation with the U.S. economy. Graph 8 illustrates the growth rates of GDP for Mexico and the U.S. after the signing of the North American 
Free Trade Agreement (NAFTA) in 1994. Notice how the changes in the trajectory of the Mexican series seem to follow the U.S. business cycle. Around 2000, for example, the U.S. slows down and enters the 2001 recession, while the drop in the growth rate of Mexico's GDP occurs in 2001. Similarly, in 2005 the U.S. economy initiates the decline that ended in the 2009 economic crisis; the slowdown of the Mexican economy begins in 2007. In fact, in 2007, when the U.S. economy was falling significantly, in Mexico policy makers and academicians insisted that Mexico's growth would continue to be robust; only to find late in 2009 a decline of almost $6 \%$ in the growth rate of GDP. ${ }^{7}$

\section{GRAPH 8}

GDP GROWTH RATES FOR MEXICO AND THE U.S. POST NAFTA

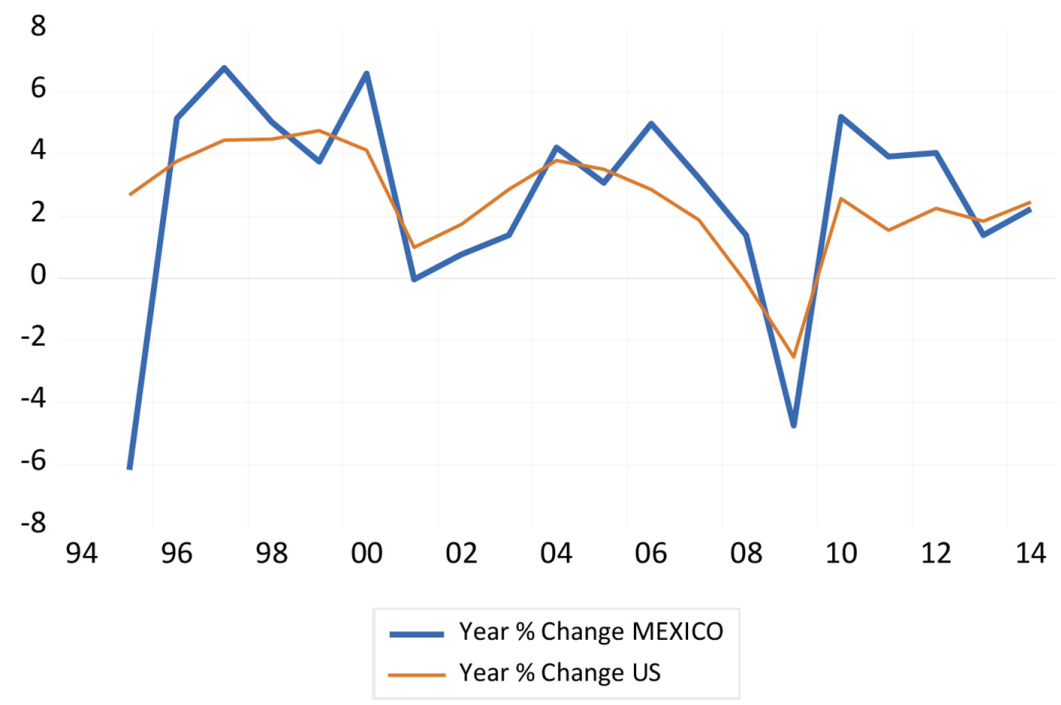

Source: Federal Reserve Economic Data

7 The infamous statement "When the U.S. has pneumonia, Mexico only has a cold" by Agustin Carstens, former Mexican Finance Minister in 2008. 


\section{Section III.II Industry Level}

We follow the methodology implemented in the previous exercise for testing for long-run and short-run associations between the variables. In this case, however, we include results for unit root tests since the stochastic nature of the series is not wellknown. Table 4 reports the statistics for the pre dollarization period and Table 5 for the series after the year 2000. We implement the Kwiatkowski-Phillips-Schmidt-Shin (KPSS) test and a modified Augmented Dickey-Fuller test to allow for structural breaks in the series. All tests, except for those series noted in the tables, are performed following a specification that allows for intercept. In all cases (perhaps with the exception of Construction before dollarization under the KPSS test), the statistics convincingly suggest that the series are integrated of order 1 . This is true even when structural breaks in the series are considered.

\section{TABLE 4}

UNIT ROOT TESTS RESULTS BEFORE DOLLARIZATION

\begin{tabular}{|l|c|c|c|c|c|}
\hline \multirow{2}{*}{} & \multicolumn{2}{|c|}{ KPSS } & \multicolumn{2}{c|}{ With Structural Break } & \multirow{2}{*}{$\begin{array}{c}\text { Order of } \\
\text { Integration }\end{array}$} \\
\cline { 2 - 5 } & Level & $\begin{array}{c}\text { First } \\
\text { Difference }\end{array}$ & Level & $\begin{array}{c}\text { First } \\
\text { Difference }\end{array}$ & \\
\hline Agriculture & 0.605 & 0.269 & -2.883 & -6.010 & I(1) \\
Commerce & 0.447 & 0.287 & -2.792 & -6.995 & I(1) \\
Construction & 0.277 & 0.213 & -3.780 & -10.217 & I(1) \\
Domestic Service & 0.489 & 0.397 & -1.917 & -8.419 & I(1) \\
Utilities & 0.750 & 0.265 & -4.723 & -8.469 & I(1) \\
Financial Services & 0.500 & 0.343 & -4.212 & -6.004 & I(1) \\
Manufacturing & 0.587 & 0.350 & -2.522 & -7.304 & I (1) \\
Oil & 0.580 & 0.278 & -3.756 & -9.044 & I(1) \\
Transport Services & 0.580 & 0.500 & -2.749 & -8.312 & I (1) \\
Other Services & 0.608 & 0.422 & -2.497 & -12.12 & \\
\hline
\end{tabular}

Critical values for the KPSS at the $1 \%, 5 \%$ and $10 \%$ levels are $0.739,0.463$, and 0.347 respectively. For the structural break test the corresponding values are $-4.949,-4.443$, and -4.194 . 


\section{TABLE 5}

UNIT ROOT TESTS RESULTS AFTER DOLLARIZATION

\begin{tabular}{|l|c|c|c|c|c|}
\hline & \multicolumn{2}{|c|}{ KPSS } & \multicolumn{2}{c|}{ With Structural Break } & \multirow{2}{*}{$\begin{array}{c}\text { Order of } \\
\text { Integration }\end{array}$} \\
\cline { 2 - 5 } & Level & $\begin{array}{c}\text { First } \\
\text { Difference }\end{array}$ & Level & $\begin{array}{c}\text { First } \\
\text { Difference }\end{array}$ & \\
\hline Agriculture & 1.157 & 0.055 & -2.493 & -7.973 & $\mathrm{I}(1)$ \\
Agriculture and Fishing (shrimp) & 1.127 & 0.066 & -2.294 & -9.266 & $\mathrm{I}(1)$ \\
Fishing (No shrimp) & 0.958 & 0.052 & -4.109 & -7.415 & $\mathrm{I}(1)$ \\
Lodging & 1.140 & 0.331 & -2.898 & -8.566 & $\mathrm{I}(1)$ \\
Commerce & 1.150 & 0.114 & -2.461 & -7.127 & $\mathrm{I}(1)$ \\
Construction & 1.112 & 0.508 & -3.517 & -6.772 & $\mathrm{I}(1)$ \\
Communications & 1.106 & 0.685 & $-1.649^{*}$ & $-6.375^{*}$ & $\mathrm{I}(1)$ \\
Domestic Service & 1.102 & 0.084 & -3.781 & -11.392 & $\mathrm{I}(1)$ \\
Utilities & 1.087 & 0.215 & $-3.137^{*}$ & $-10.063^{*}$ & $\mathrm{I}(1)$ \\
Education and Health & 1.151 & 0.159 & -2.674 & -12.124 & $\mathrm{I}(1)$ \\
Financial & 1.124 & 0.130 & -2.784 & -10.964 & $\mathrm{I}(1)$ \\
Manufacturing & 1.144 & 0.334 & -2.597 & -6.784 & $\mathrm{I}(1)$ \\
Oil and Mining & 0.817 & 0.179 & $-4.257^{*}$ & $-6.433^{*}$ & $\mathrm{I}(1)$ \\
Professional Services & 1.120 & 0.592 & -3.680 & -8.660 & $\mathrm{I}(1)$ \\
Public Administration & 1.141 & 0.137 & -4.550 & -9.864 & $\mathrm{I}(1)$ \\
Oil (refining) & 0.729 & 0.105 & $-3.871^{*}$ & $-8.802^{*}$ & $\mathrm{I}(1)$ \\
Transport Services & 1.141 & 0.204 & -2.001 & -10.129 & $\mathrm{I}(1)$ \\
Other Services & 1.022 & 0.225 & -3.045 & -6.996 & $\mathrm{I}(1)$ \\
\hline
\end{tabular}

* In these cases the statistics correspond to the test considering trend and intercept in the estimating equation Critical values for the KPSS at the $1 \%, 5 \%$ and $10 \%$ levels are $0.739,0.463$, and 0.347 respectively. For the structural break test the corresponding values are $-4.949,-4.443$, and -4.194 .

We proceed to estimate cointegrating equations. Table 6 and Table 7 report the results for the pre and post dollarization periods respectively. We find evidence of a common trend between production in Ecuador and the U.S. for all sectors in both periods. Although no direct comparison can be made for every industry, we find that overall the responsiveness of Ecuadorian industries to the economy of the U.S. has increased; the average elasticity prior to 2000 is 0.939 while the same is 1.522 after the dollar was adopted. Evidence of this increase for specific industries is found for Commerce, Construction, Domestic Service, Financial Services, Manufacturing, and Other Services. The case of the financial sector is particularly interesting. Before the dollar was adopted, the elasticity of this industry with respect to U.S. GDP was 0.456, the smallest of all coefficients in the pre dollarization period. After 2000, the elasticity became 1.763, almost a fourfold increase. This result illustrates how the financial market in Ecuador has become more responsive to the performance of the U.S. economy in long-run horizons. 
TABLE 6

COINTEGRATING EQUATIONS PRE DOLLARIZATION

\begin{tabular}{|l|c|c|c|}
\hline \multirow{2}{*}{ System: US GDP and } & \multirow{2}{*}{ Probability } & \multicolumn{2}{|c|}{ Normalized } \\
\cline { 3 - 4 } & & \multicolumn{2}{|c|}{ Cointegration Vector } \\
\hline Agriculture & 0.000 & 1.000 & -1.217 \\
Commerce & 0.000 & 1.000 & -1.183 \\
Construction & 0.000 & 1.000 & -0.845 \\
Domestic Service & 0.000 & 1.000 & -0.696 \\
Utilities & 0.000 & 1.000 & -0.743 \\
Financial Services & 0.000 & 1.000 & -0.456 \\
Manufacturing & 0.000 & 1.000 & -1.118 \\
Oil & 0.000 & 1.000 & -1.083 \\
Transport Services & 0.000 & 1.000 & -1.004 \\
Other Services & 0.000 & 1.000 & -1.049 \\
\hline
\end{tabular}

The null hypothesis is No-Cointegrating vector. The cointegration vector is normalized with respect to Ecuador's industries.

TABLE 7

COINTEGRATING EQUATIONS POST DOLLARIZATION

\begin{tabular}{|l|c|c|c|}
\hline \multirow{2}{*}{ System: US GDP and } & \multirow{2}{*}{ Probability } & \multicolumn{2}{|c|}{ Normalized } \\
\cline { 3 - 4 } & & \multicolumn{2}{|c|}{ Cointegration Vector } \\
\hline Agriculture & 0.000 & 1.000 & -2.061 \\
Agriculture and Fishing (shrimp) & 0.018 & 1.000 & -3.962 \\
Fishing (No shrimp) & 0.000 & 1.000 & -1.197 \\
Lodging & 0.000 & 1.000 & -1.365 \\
Commerce & 0.004 & 1.000 & -1.535 \\
Construction & 0.000 & 1.000 & -1.595 \\
Communications & 0.001 & 1.000 & -1.511 \\
Domestic Service & 0.000 & 1.000 & -1.081 \\
Utilities & 0.024 & 1.000 & -0.417 \\
Education and Health & 0.000 & 1.000 & -1.442 \\
Financial & 0.009 & 1.000 & -1.763 \\
Manufacturing & 0.004 & 1.000 & -1.545 \\
Oil and Mining & 0.003 & 1.000 & -1.394 \\
Oil (refining) & 0.007 & 1.000 & -1.493 \\
Professional Services & 0.000 & 1.000 & -1.447 \\
Public Administration & 0.001 & 1.000 & -0.967 \\
Transport Services & 0.000 & 1.000 & -0.991 \\
Other Services & 0.031 & 1.000 & -1.624 \\
\hline
\end{tabular}

The null hypothesis is No-Cointegrating vector. The cointegration vector is normalized with respect to Ecuador's industries. 
Table 8 presents the results of the common cycle tests for the sample period before 2000. Table 9 reports the same for the post dollarization period. The statistics suggest the existence of a common cycle for four industries in the pre dollarization period and seven thereafter (those highlighted in the tables under Probability). Prior to 2000 only one sector, Transport Services showed both, a common cycle and a significant response to transitory shocks in the U.S. economy, with a coefficient of 0.078 and a t-statistic of 2.137. Construction responds significantly to transitory changes in the U.S. economy but does not share a common cycle; the t-statistic is 2.097 but the probability of a common cycle is only 0.015 . After 2000, three industries reported significant short run coefficients: Commerce, Financial, and Public Administration. In all three cases there is also evidence of a common cycle with the U.S. business cycle; the probability is greater than 0.05 . The other four industries that report a common cycle: Lodging, Utilities, Transport Services and Other Services, do not present a significant coefficient. That means that while the turning points in the cycles of the series are similar, the effect of a transitory change in the U.S. business cycle does not impact significantly economic activity in these industries. In sum, the econometric evidence clearly shows an increase in economic interrelation between Ecuador and the U.S. at the industry level.

\section{TABLE 8}

RESULTS OF COMMON CYCLES PRE DOLLARIZATION

\begin{tabular}{|l|c|c|c|}
\hline System: US GDP and & Probability & $\begin{array}{c}\text { Two Stage Least } \\
\text { Square Estimate }\end{array}$ & t-statistic \\
\hline Agriculture & 0.159 & 0.029 & 0.458 \\
Commerce & 0.224 & 0.049 & 0.700 \\
Construction & 0.015 & 0.056 & 2.097 \\
Domestic Service & 0.022 & -0.024 & -0.341 \\
Utilities & 0.011 & 0.004 & 0.208 \\
Financial Services & 0.007 & -0.013 & -0.685 \\
Manufacturing & 0.033 & -0.032 & -0.439 \\
Oil & 0.161 & -0.005 & -0.152 \\
Transport Services & 0.469 & 0.078 & 2.137 \\
Other Services & 0.025 & 0.006 & 0.083 \\
\hline
\end{tabular}

The null hypothesis refers to the existence of a common cycle. Highlighted cells under Probability show systems for which there is evidence of a common cycle at conventional significance levels. Highlighted cells under t-statistic identify significant coefficients. 


\section{TABLE 9}

RESULTS OF COMMON CYCLES POST DOLLARIZATION

\begin{tabular}{|l|c|c|c|}
\hline System: US GDP and & Probability & $\begin{array}{c}\text { Two Stage Least } \\
\text { Square Estimate }\end{array}$ & t-statistic \\
\hline Agriculture & 0.003 & -0.081 & -0.866 \\
Agriculture and Fishing (shrimp) & 0.009 & -0.013 & -0.573 \\
Fishing (No shrimp) & 0.002 & 0.020 & 0.727 \\
Lodging & 0.206 & -0.126 & -1.292 \\
Commerce & 0.158 & 0.201 & 2.045 \\
Construction & 0.000 & -0.060 & -1.275 \\
Communications & 0.004 & 0.016 & 0.357 \\
Domestic Service & 0.022 & -0.057 & -1.938 \\
Utilities & 0.432 & 0.031 & 0.752 \\
Education and Health & 0.005 & -0.036 & -0.643 \\
Financial & 0.113 & 0.085 & 1.649 \\
Manufacturing & 0.003 & 0.112 & 1.007 \\
Oil and Mining & 0.038 & 0.059 & 1.738 \\
Oil (refining) & 0.020 & 0.002 & 0.213 \\
Professional Services & 0.032 & 0.110 & 1.496 \\
Public Administration & 0.421 & -0.131 & -1.828 \\
Transport Services & 0.273 & -0.298 & -1.531 \\
Other Services & 0.053 & 0.166 & 1.058 \\
\hline
\end{tabular}

The null hypothesis refers to the existence of a common cycle. Highlighted cells under Probability show systems for which there is evidence of a common cycle at conventional significance levels. Highlighted cells under t-statistic identify significant coefficients.

Although our results provide convincing evidence of the effects of dollarization on various economic indicators for Ecuador, it is worth highlighting what we indicated in the introduction; there exists the possibility that the synchronization we identified across U.S. and Ecuadorian variables may not necessarily be associated with the adoption of the U.S. dollar. Specifically, the economics literature has identified the existence of super cycles. These are cycles that span for long periods of time and are evident in a broad range of economic variables, particularly commodity prices. These events generate cyclical patterns shared by economies around the world. Erten and Ocampo (2013), for instance, identify the emergence of super cycles since the early 1800 s, including one that started in the early 2000s. Hence, it is possible that these super cycles have contributed to the existence of comovements across the economic variables we examined. Ideally, one would assess to what extent the common cycles we identified are the result of the super cycles and/or dollarization. While the availability of data and sample size in our exercise make this estimation unfeasible, we can at 
least shed some light in disentangling the source of synchronization. In Table 10 we report cointegration and common cycle tests results for private credit in Ecuador and consumer credit in the U.S. Reasonably, one can argue that for these type of variables it is more likely that the source of integration is dollarization and not the presence of a super cycle. Specifically, commodities constitute a significant component of Ecuador's economy, and hence, a super cycle may be influencing the cyclical behavior of production variables. Financial variables such as those representative of the credit market, on the other hand, are not as exposed to commodity fluctuations. In fact, Quispe-Agnoli and Whisler (2006) describe the effects that dollarization may have on financial markets. In the particular case of the banking system, the authors highlight the importance of dollarization as a mechanism of stabilization and the consequent improvement in banking efficiency. Dollarization restores confidence in the currency and banking institutions, promoting deposits and lending in an overall more robust banking system. Similarly, Gale and Vives (2002) show that dollarization reduces the problems associated with moral hazard, which leads to a more developed banking system. Arellano and Heathcote (2010) note that strengthening domestic financial markets allows for increased international financial integration.

TABLE 10

COINTEGRATION AND COMMON CYCLE RESULTS FOR THE CREDIT MARKET

\begin{tabular}{|l|c|c|c|}
\hline $\begin{array}{l}\text { Ecuador Private Credit, U.S. } \\
\text { Consumer Credit }\end{array}$ & Probability & $\begin{array}{c}\text { Normalized Cointegrating } \\
\text { Vector }\end{array}$ & \\
\hline Before Dollarization & 0.000 & 1 & -1.282 \\
After Dollarization & 0.000 & 1 & -1.564 \\
\hline
\end{tabular}

The null hypothesis is No-Cointegrating vector. The cointegration vector is normalized with respect to Ecuador's GDP.

\begin{tabular}{|l|c|c|c|}
\hline $\begin{array}{l}\text { Ecuador Private Credit, U.S. } \\
\text { Consumer Credit }\end{array}$ & Probability & $\begin{array}{c}\text { Two Stage Least Square } \\
\text { Estimate }\end{array}$ & t-statistic \\
\hline Before Dollarization & 0.000 & 0.095 & 1.268 \\
After Dollarization & 0.316 & 0.442 & 3.586 \\
\hline
\end{tabular}

The null hypothesis refers to the existence of a common cycle.

The results in the table suggests the existence of common trends before and after dollarization, with a larger effect identified in the post dollarization period. The absence of synchronization is evident prior to dollarization. For the post-dollarization period, the results clearly indicate the synchronization of cycles and a statistically 
significant association between credit in Ecuador and credit in the U.S. In particular, prior to dollarization the probability of a common cycle across credit in Ecuador and in the U.S. is zero; after adopting the U.S. dollar this probability increases to 0.316 . Also, while the two stage least square estimator before 2000 is non-significant, the coefficient for the post dollarization period shows a magnitude of 0.442 and a t-statistic of 3.586. That is, the credit market in Ecuador not only shares transitory movements with credit in the U.S., but also responds significantly to changes in credit conditions.

The results of the econometric tests are consistent with the illustration of the variables in Graphs 9 and 10. Notice that prior to 2000 credit in Ecuador does not follow the cyclical patterns of consumer credit in the U.S. After 2000, both series present an upward trend and the ups and downs of U.S. credit are reflected in the fluctuations of credit in Ecuador; this is clearly the case for the decline in credit during the 2008-2010 slowdown.

Although we are not able to offer a thorough analysis of the source of synchronization across economic variables in Ecuador and the U.S,, the results from this exercise with financial variables clearly suggest that dollarization affected cyclical patterns in Ecuadorian variables, and hence, it is very likely the source of the synchronization identified in production variables.

\section{GRAPH 9}

\section{CONSUMER CREDIT PRIOR TO DOLLARIZATION}

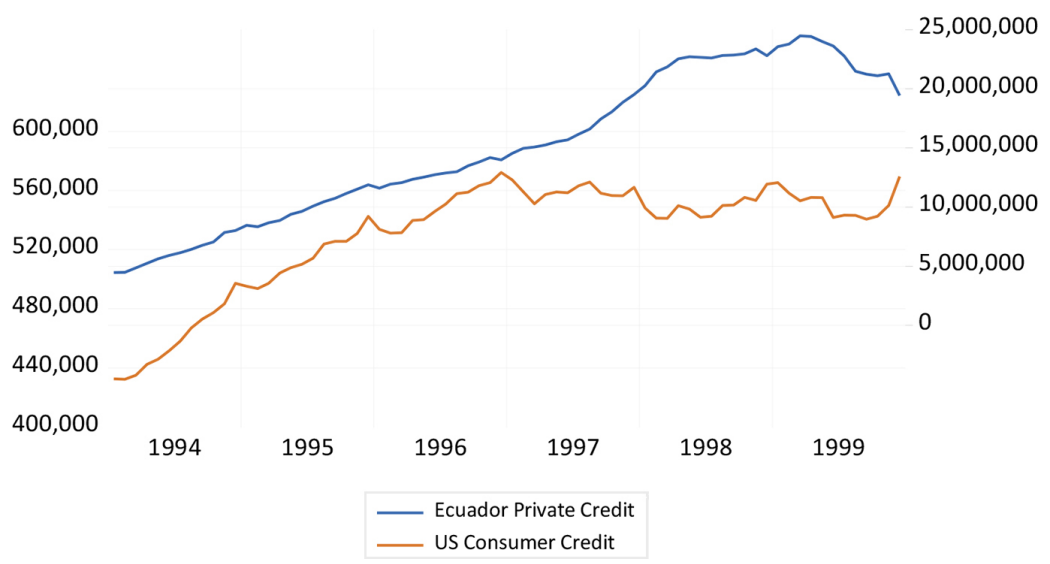




\section{GRAPH 10}

\section{CONSUMER CREDIT POST DOLLARIZATION}

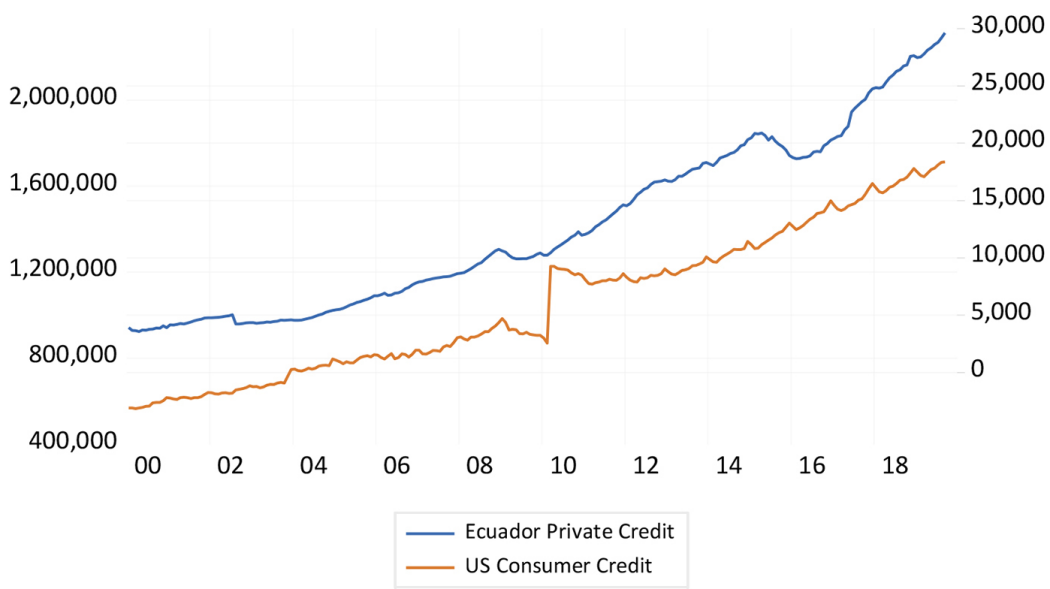

\section{SECTION IV. CONCLUSION}

Dollarization is an issue that has been discussed exhaustively in policy making and academic circles. For the most part, the interest has centered on determining the net effect that this policy has produced for the adopting country. In this paper we departed from the traditional analysis and focused on an implication of dollarization that has received little attention in the literature: economic integration with the anchor country. By estimating cointegration and common cycle tests we were able to determine that the economy of Ecuador was integrated with the U.S. economy at the aggregate and industry levels prior to dollarization, and that such integration deepened after Ecuador adopted the U.S. dollar as its currency. The results at the aggregate level also identified a leader-follower dynamic in the business cycles of both countries, with the Ecuadorian economy responding to transitory changes in the U.S. business cycles with lags. It takes at least one quarter for the economy in Ecuador to respond to a fluctuation of economic activity in the U.S. Perhaps more interesting, we found that the financial industry in Ecuador has become more responsive to economic activity in the U.S. in the long-run and in the short-run. The response is contemporaneous in the case of transitory episodes. While this result is consistent with economic theory, we did not pursue determining the causes of the phenomenon. Clearly, a thorough examination of the mechanisms whereby financial markets in Ecuador have become more integrated with the U.S. economy is necessary. 


\section{REFERENCES}

ARELLANO, C. and J. HEATHCOTE (2010). "Dollarization and Financial Integration”, Journal of Economic Theory 145 (3), pp. 944-973.

BEVERIDGE, S. and C. NELSON (1981). "A New Approach to Decomposition of Economic Time Series into Permanent and Transitory Components with Particular Attention to Measurement of the Business Cycle", Journal of Monetary Economics 7 (2), pp. 151-174.

BERG, A. and E. BORENSZTEIN (2000). "The Pros and Cons of Full Dollarization", IMF Working Paper WP/00/50.

CASTILLO-PONCE, R. and M. RODRIGUEZ-ESPINOSA (2009). "La Dolarización de El Salvador: ¿Una Contribución Negativa al Crecimiento Económico?”, Comercio Exterior 59 (11), pp. 898-909.

CHRISTOPOULOS, D. and M. TSIONAS (2004). "Financial Development and Economic Growth: Evidence from Panel Unit Root and Cointegration Tests", Journal of Development Economics 73 (1), pp. 55-74.

GALE, D. and X. VIVES (2002). "Dollarization, Bailouts, and the Stability of the Banking System", The Quarterly Journal of Economics 117 (2), pp. 467-502.

GONZALEZ A.; A. MICCO and A. M. MONTOYA (2015). "Dollarization, Foreign ownership, and Competition in the Banking Industry in Latin America", Emerging Markets Finance and Trade 51 (1), pp. 90-107.

ERTEN, B. and J. A. OCAMPO (2015). "Super Cycles of Commodity Prices Since the Mid-Nineteenth Century", World Development 44, pp. 14-30.

HERRERA, J. (2004). "Business Cycles in Mexico and the United States: Do They Share Common Movements?", Journal of Applied Economics 7 (2), pp. 303-323.

JOHANSEN, S. (1991). "Estimation and Hypothesis Testing of Cointegration Vectors in Gaussian Vector Autoregressive Models", Econometrica 59 (6), pp. 1551-1580.

LANGE, C. and C. SAUER (2005). "Dollarization in Latin America: Seigniorage Costs and Policy Implications", The Quarterly Review of Economics and Finance 45 (4-5), pp. 662-679.

LAKI囚 S.; D. ŠEHOVI囚 and J. 『ETKOVI区 (2016). "An Analysis of the Official Dollarization Regime in Montenegro: Theoretical Approaches and Empirical Evidence", Journal of International Studies 9 (2), pp. 48-64.

LINDENBERG, N. and F. WESTERMANN (2012). "Common Trends and Common Cycles among Interest Rates of the G7-Countries", Journal of Macroeconomics 34 (4), pp. 1125-1140.

MARÍ DEL CRISTO, M. and M. GÓMEZ-PUIG (2016). "Fiscal Sustainability and Dollarization the Case of Ecuador", Applied Economics 48 (23), pp. 2139-2155.

MUSA, M. (1986). "Nominal Exchange Rate Regimes and the Behavior of Real Exchange Rate Regimes: Evidence and Implications", Carnegie-Rochester Conference Series on Public Policy 25, pp. 117-214.

PERRON, P. and T. WADA (2009). "Let's Take a Break: Trends and Cycles in U.S. Real GDP”, Journal of Monetary Economics 56 (6), pp. 749-765.

QUISPE-AGNOLI, M. and E. WHISLER (2006). "Official Dollarization and the Banking System in Ecuador and El Salvador", Economic Review 91 (3), pp. 55-71.

RODRIGUEZ, M. and J. DOMBROW (2015). "Dollarization and Real Estate Market Performance: Evidence from Housing in El Salvador", Journal of Housing Research 24 (1), pp. 37-53.

SANDOVAL L.; J. MALAGA and C. CARPIO (2015). "Analysis of the Impact of Dollarization and CAFTA-DR on El Salvador's Trade Flows", Southern Agricultural Economics Association's 2015 Annual Meeting.

SOTO, R. (2009). "Dollarization, Economic Growth, and Unemployment", Economics Letters 105 (1), pp. $42-45$.

YEPES, J. (2016). "Dollarization and Growth: A Synthetic Control Approach to Ecuador and El Salvador's Cases", Master's Thesis, Baylor University.

VAHID, F. and R. Engle (1993). "Common Trends and Common Cycles", Journal of Applied Econometrics 8 (4), pp. 341-360. 